\title{
The influence of heartwood on the pulping properties of Acacia melanoxylon wood
}

Received: April 24, 2008 / Accepted: June 20, 2008 / Published online: September 4, 2008

\begin{abstract}
The pulping wood quality of Acacia melanoxylon was evaluated in relation to the presence of heartwood. The sapwood and heartwood from 20 trees from four sites in Portugal were evaluated separately at $5 \%$ stem height level in terms of chemical composition and kraft pulping aptitude. Heartwood had more extractives than sapwood ranging from $7.4 \%$ to $9.5 \%$ and from $4.0 \%$ to $4.2 \%$, respectively, and with a heartwood-to-sapwood ratio for extractives ranging from 1.9 to 2.3. The major component of heartwood extractives was made up of ethanol-soluble compounds $(70 \%$ of total extractives). Lignin content was similar in sapwood and heartwood $(21.5 \%$ and $20.7 \%$, respectively) as well as the sugar composition. Site did not influence the chemical composition. Pulping heartwood differed from sapwood in chemical and optical terms: lower values of pulp yield (53\% vs $56 \%$ respectively), higher kappa number (11 vs. 7), and lower brightness (28\% vs $49 \%$ ). Acacia melanoxylon wood showed an overall good pulping aptitude, but the presence of heartwood should be taken into account because it decreases the raw-material quality for pulping. Heartwood content should therefore be considered as a quality variable when using $A$. melanoxylon wood in pulp industries.
\end{abstract}

Key words Acacia melanoxylon - Heartwood - Sapwood · Extractives $\cdot$ Pulp yield

\section{Introduction}

Acacia is a genus of trees and shrubs belonging to the subfamily Mimosoideae of the family Fabaceae with over 1500 species and a large diversity of soil occupation. ${ }^{1,2}$ Acacia

A. Lourenço $\cdot$ I. Baptista $\cdot$ J. Gominho $(\bowtie) \cdot$ H. Pereira

Centro de Estudos Florestais, Instituto Superior de Agronomia, Universidade Técnica de Lisboa, Tapada da Ajuda, Lisbon 1349-017, Portugal

Tel. +351-21-369-3378; Fax +351-21-364-5000

e-mail: jgominho@isa.utl.pt spp. are originally from Tasmania, Australia, but are now widespread in different regions. Some were brought to Europe as ornamentals, to stabilize dunes, and for timber applications and tanning. ${ }^{3}$ In Portugal, they were introduced in the mid-nineteenth century and several species, mostly Acacia melanoxylon, Acacia dealbata, and Acacia longifolia, are distributed over the country, especially in the Atlantic zone. ${ }^{4}$ They are now considered as invaders due to their capacity for adaptation to low fertility soils, resistance, and high growth rate, which reduce development of autochthonous species. ${ }^{5}$ Suggestions have been made for the use of acacia trees for timber and pulp, and as a strategic measure to avoid its uncontrolled spread.

Acacia trees are used for several purposes, including furniture, woodcraft products and pulp, ${ }^{6}$ charcoal and firewood, ${ }^{7}$ and gum extraction for food and pharmaceutical products. ${ }^{8}$ They are considered as valuable forest species and commercial plantations have been established in Australia, New Zealand, China, South Africa, and Chile.,

One of the uses of acacia wood is pulping and several studies have shown its applicability with different processes such as kraft, soda-anthraquinone (soda-AQ), modified sulfite-AQ (ASA), and sulfite-AQ-methanol (ASAM). Pulp yield values range from $42 \%$ to $56 \%$, kappa numbers between 11 and 22, and ISO brightness between $20 \%$ to $45 \%$. $^{7,9,10-13}$ The kraft pulps from $A$. melanoxylon and $A$. dealbata showed good results regarding several properties, particularly in comparison with Eucalyptus globulus pulp, ${ }^{9}$ as well as alkaline peroxide mechanical pulps. ${ }^{14}$ According to Paavilainen, ${ }^{15}$ the future main source of pulpwood in Asia will be fast-growing Acacia and Eucalyptus plantations.

When considering the pulping quality of tree stems, heartwood is an important variable, mainly because its high extractive content compared with sapwood leads to higher consumption of bleaching chemicals and lower pulp yield and brightness. ${ }^{16-20}$ Heartwood is present in considerable proportion in tree stems, even in young pulpwood plantations of fast-growing species, such as eucalypts. ${ }^{20-22}$ In $A$. melanoxylon, the heartwood amount is considerable, representing $61 \%$ of the total tree volume, and it seems to be 
influenced by environment rather than by genetic factors. ${ }^{23,24}$ A number of secondary metabolites were reported for various Acacia species, the best known being gums and condensed tannins. ${ }^{2}$

An assessment of the pulpwood quality of $A$. melanoxylon trees should therefore include an evaluation of heartwood extractives and of their influence in pulping. This is the aim of the present study where extractives and their impact on pulp yield and properties were studied using heartwood and sapwood of different A. melanoxylon trees grown in four sites.

\section{Materials and methods}

\section{Site characterization and sampling}

The study was made with 20 trees of Acacia melanoxylon $\mathrm{R}$. Br., with ages in the range of 28-43 years, from four locations in Portugal ( 5 trees from each site): site 1, Caminha; site 2, Ponte de Lima; site 3, Viseu; and site 4, Ovar. Geographic and edapho-climatic characterization was described elsewhere by Knapic et al. ${ }^{23}$ The trees reached, on average, $30 \mathrm{~m}$ in height and $40 \mathrm{~cm}$ in breast height diameter. The heartwood attained $67 \%$ to $85 \%$ of tree total height and represented in cross section, on average, $69 \%$ at the stem base, decreasing to $26 \%$ at $75 \%$ of total height. ${ }^{23}$

Chemical analysis and pulping were performed on a 5$\mathrm{cm}$-thick disc collected at 5\% of total height (corresponding to a mean height of $1.5 \mathrm{~m}$ ), where the heartwood proportion ranged from $60 \%$ to $75 \%$ of the cross-sectional area. The sapwood and heartwood were separated on each disc with a chisel and milled in a knife mill (Retsch SM 2000), and sieved (Retsch ISO 9001). The 40-60 mesh granulometric fraction was kept for chemical analysis and the 20-40 mesh fraction for pulping.

\section{Chemical analysis}

The content of extractives was determined by using a Soxhlet extraction system with dichloromethane, ethanol, and water as solvents, as adapted from Tappi 12 os-75. Klason and acid-soluble lignin content were determined in extractive-free material following Tappi 222 om-02 and Tappi UM 250 methods, respectively. The carbohydrate composition was determined by gas-liquid chromatography with a method adapted from Tappi $249 \mathrm{~cm}-00$. The hydrolyzed carbohydrates were derivatized as alditol acetates and separated by gas chromatography (GC; HP 5890A, Agilent) with flame-ionization detection (FID), helium as carrier gas (1 $\mathrm{ml} / \mathrm{min})$, and a fused silica capillary column S2330 $(30 \mathrm{~m} \times 0.32 \mathrm{~mm}$ i.d. $\times 0.20 \mu \mathrm{m}$ film thickness $)$. The column program temperature was $225^{\circ}-250^{\circ} \mathrm{C}$, with $5^{\circ} \mathrm{C} / \mathrm{min}$ heating gradient, and the temperature of injector and detector was $250^{\circ} \mathrm{C}$. For quantitative analysis, the GC was calibrated with pure reference compounds and inositol was used as an internal standard in each run.
Pulping

Pulping experiments were carried out with eight stem discs (two discs per site) selected as having the highest $(\mathrm{H})$ and an average $(\mathrm{M})$ value of heartwood extractives content. Kraft pulps were produced in 100-ml stainless steel autoclaves rotated (microdigesters) in an oil bath with temperature control. The 20-40 mesh fractions of heartwood and sapwood that were used had an average particle length of $1.79 \mathrm{~mm}$ and a thickness of $0.29 \mathrm{~mm}$, as measured by image analysis. These dimensions are adequate to reduce the influence of chip size on the diffusion process during pulping and it can be assumed that the liquor penetration rate in the wood chips is infinite. The pulping conditions were: liquor-to-wood ratio ( $\mathrm{ml} / \mathrm{g}$ ) 4.5:1; sulfidity 30\%; active alkali $20 \%\left(\right.$ as $\left.\mathrm{Na}_{2} \mathrm{O}\right)$; cooking temperature $170^{\circ} \mathrm{C}$; time at temperature $90 \mathrm{~min}$; heating time to temperature $5 \mathrm{~min}$. The calculated $H$-factor was 1387 ( $H$-factor in heat-up time: 9; $H$-factor in cooking: 1378). At the end of pulping, the pulps were defibrated in a standard pulp disintegrator, thoroughly washed with deionized water, air-dried overnight in a climate-controlled room $\left(55 \%\right.$ relative humidity and $25^{\circ} \mathrm{C}$, as described in Tappi 402 os-70), transferred to an oven at $60^{\circ} \mathrm{C}(6 \mathrm{~h})$, changed to $100^{\circ} \mathrm{C}(1 \mathrm{~h})$, and weighed for yield determination. This procedure was previously tested to verify that the samples achieved a constant weight. All pulping experiments were replicated and if the pulp yields differed by more than 0.5 they were rejected and the process was repeated.

\section{Pulp characterization}

The A. melanoxylon pulps were extracted by dichloromethane and a solution $(1: 1)$ of ethanol and water using a Soxhlet extraction system to remove residuals of extractable material. Chemical characterization of pulps included the determination of residual lignin as kappa number measured automatically with a Titralab Radiometer Analytical equipment (Tappi 236 os-76), cellulose polymerization measured as intrinsic CED viscosity (SCAN-CM 15:88), and content of hexeneuronic acid groups $\left(C_{\text {hexA }}\right)$ determined by ultraviolet (UV) spectrophotometry (Shimadzu, UV160A) according to the method established by Chai et al. ${ }^{25}$ using hydrolysis of $30 \mathrm{mg}$ of pulp in a mercuric chloride $(0.6 \%)$-sodium acetate $(0.7 \%)$ solution $(10 \mathrm{ml})$. Pulp color was characterized by CIE $L^{*} a^{*} b^{*}$ scale and brightness (Tappi 452 om-02) with a Minolta CM-3630 spectrophotometer. Statistical analysis was conducted using SAS for Windows version 9.13 and a significance level of 0.05 .

\section{Results and discussion}

\section{Chemical composition}

The analysis of sapwood and heartwood of the Acacia melanoxylon trees in the four sites is summarized in Table 1 . The overall mean composition was $6.2 \%$ for total extractives 
and $21.0 \%$ for total lignin with $18.6 \%$ Klason lignin. The sugar composition is summarized in Table 2. Glucose and xylose are the main monosaccharide units, with values ranging respectively from $67.2 \%$ to $69.5 \%$ and from $22.5 \%$ to $26.1 \%$. Together, arabinose and galactose represent about $2.6 \%$ of the total content of neutral sugars, and these sugar compositions agree with the general structure of hardwood hemicelluloses. ${ }^{26,27}$

There are very few published references on the chemical composition of Acacia wood. For A. melanoxylon, Santos et al. ${ }^{9,28}$ reported $3.2 \%$ total extractives and $17.5 \%$ total lignin. For other Acacia species, Collins et al. ${ }^{13}$ reported $5.8 \%$ total extractives, $21.7 \%$ Klason lignin, and $69.8 \%$ polysaccharides for Acacia auriculiformis; Santos et al. ${ }^{9}$ reported $3.5 \%$ extractives and $18.2 \%$ Klason lignin for Acacia dealbata; and Neto et al. ${ }^{11}$ and Pinto et al. ${ }^{10}$ reported $4.5 \%$ ethanol/toluene extractives, $27.6 \%$ Klason lignin, and $61.0 \%$ polysaccharides for Acacia mangium.

In relation to other fast-growing pulp woods, for instance eucalypts, A. melanoxylon shows similar values of lignin content. For example, the lignin content of Eucalyptus globulus has been reported in the range of $20.9 \%-$ $27.0 \%$. $^{9,11,29,30}$

Comparison of the heartwood and sapwood fractions of A. melanoxylon trees shows chemical differences in terms of the extractives content (Table 1). Heartwood had more extractives than sapwood $(7.4 \%-9.5 \%$ and $4.0 \%-4.2 \%$, respectively) and the heartwood-to-sapwood ratio for extractives varied from 1.9 to 2.3. This increase in extractives was mainly due to an accumulation of ethanol-soluble compounds in heartwood, where they represented more than $70 \%$ of the total extractives ( $40 \%$ in sapwood). The content of dichloromethane-soluble extractives was negligible $(0.4 \%)$, while ethanol-soluble and water-soluble extractives reached an average of $5.9 \%$ and $1.8 \%$ in heartwood and $2.0 \%$ and $1.7 \%$ in sapwood, respectively. There was no difference between heartwood and sapwood regarding the structural components, with a mean lignin content of $20.7 \%$ in heartwood and $21.5 \%$ in sapwood and a very similar carbohydrate composition of hemicelluloses (Tables 1 and 2).

It is known that the higher content in extractives of heartwood results from an enrichment process that occurs during heartwood formation and is cumulative along the tree's lifetime. ${ }^{31}$ Comparative studies of heartwood-sapwood extractives in other hardwood species have shown similar results: for instance, in E. globulus respectively $5.7 \%$ and $3.5 \%{ }^{22}$ and $4.6 \%$ and $2.6 \%,{ }^{32}$ and in the urograndis eucalypt hybrid $7.6 \%$ and $3.7 \% .^{33}$

Overall there was very little chemical variation between the A. melanoxylon trees in this study. The extractive content in sapwood and heartwood was not influenced by the sites where the trees had grown, as showed by a StudentNewman-Keuls $(\alpha=0.05)$ comparative test of means. The between-tree variation was also small and could not be ascertained to differences in tree dimensions, because only weak or no correlations were found between extractives in heartwood and sapwood and the corresponding crosssectional area $(r=0.38 ; P<0.1$ and $r=0.10$; not significant, respectively). Nevertheless, smaller heartwood diameter seemed to be associated to higher contents of total extractives (Fig. 1).

The visual distinction between sapwood and heartwood was quantified with color parameters (Fig. 2). Sapwood had higher luminosity $\left(L^{*}\right)$ than heartwood (77 and 55, respectively) and lower $a^{*}$ values (4.8 and 11.3, respectively), meaning that heartwood is redder, while $b^{*}$ values were similar (20.4 and 22.4, respectively).

Table 1. Extractives and lignin content of sapwood and heartwood from Acacia melanoxylon grown in four different sites

\begin{tabular}{|c|c|c|c|c|c|c|c|c|}
\hline \multirow[t]{2}{*}{ Analysis } & \multicolumn{4}{|l|}{ Sapwood } & \multicolumn{4}{|c|}{ Heartwood } \\
\hline & Site 1 & Site 2 & Site 3 & Site 4 & Site 1 & Site 2 & Site 3 & Site 4 \\
\hline Total extractives & $4.1 \pm 0.3$ & $4.0 \pm 0.4$ & $4.2 \pm 0.5$ & $4.1 \pm 0.7$ & $9.5 \pm 1.2$ & $7.4 \pm 2.5$ & $8.1 \pm 3.9$ & $7.6 \pm 2.4$ \\
\hline Dichloromethane & $0.4 \pm 0.3$ & $0.3 \pm 0.1$ & $0.3 \pm 0.1$ & $0.4 \pm 0.2$ & $0.5 \pm 0.1$ & $0.3 \pm 0.1$ & $0.4 \pm 0.1$ & $0.3 \pm 0.1$ \\
\hline Ethanol & $1.9 \pm 0.3$ & $2.0 \pm 0.2$ & $2.2 \pm 0.4$ & $1.9 \pm 0.8$ & $7.3 \pm 1.2$ & $5.3 \pm 2.3$ & $5.8 \pm 4.9$ & $5.3 \pm 2.4$ \\
\hline Water & $1.7 \pm 0.2$ & $1.7 \pm 0.2$ & $1.7 \pm 0.2$ & $1.8 \pm 0.2$ & $1.7 \pm 0.2$ & $1.8 \pm 0.3$ & $1.9 \pm 0.2$ & $2.0 \pm 0.3$ \\
\hline Total lignin & $21.0 \pm 0.7$ & $21.9 \pm 0.5$ & $22.2 \pm 1.2$ & $20.8 \pm 0.8$ & $20.5 \pm 0.8$ & $20.8 \pm 07$ & $20.9 \pm 1.1$ & $20.5 \pm 1.6$ \\
\hline Klason lignin & $18.4 \pm 0.6$ & $19.3 \pm 0.4$ & $19.8 \pm 0.6$ & $18.1 \pm 0.8$ & $17.9 \pm 0.9$ & $18.2 \pm 0.9$ & $18.7 \pm 0.8$ & $17.9 \pm 1.1$ \\
\hline Soluble lignin & $2.6 \pm 0.7$ & $2.6 \pm 0.2$ & $2.4 \pm 0.6$ & $2.8 \pm 0.4$ & $2.5 \pm 0.4$ & $2.7 \pm 0.5$ & $2.2 \pm 0.4$ & $2.6 \pm 0.5$ \\
\hline
\end{tabular}

Data given as mean \pm standard deviation $(n=5)$ as percentage of oven-dried wood

Table 2. Sugar composition of sapwood and heartwood from A. melanoxylon grown in four different sites

\begin{tabular}{|c|c|c|c|c|c|c|c|c|}
\hline \multirow[t]{2}{*}{ Sugar } & \multicolumn{4}{|l|}{ Sapwood } & \multicolumn{4}{|l|}{ Heartwood } \\
\hline & Site 1 & Site 2 & Site 3 & Site 4 & Site 1 & Site 2 & Site 3 & Site 4 \\
\hline Arabinose & $1.9 \pm 1.7$ & $1.6 \pm 0.5$ & $1.6 \pm 0.7$ & $1.7 \pm 0.6$ & $1.1 \pm 0.3$ & $2.2 \pm 1.9$ & $1.3 \pm 0.4$ & $1.8 \pm 0.8$ \\
\hline Xylose & $24.1 \pm 1.9$ & $25.2 \pm 1.2$ & $25.4 \pm 2.3$ & $23.3 \pm 0.7$ & $26.1 \pm 0.4$ & $24.6 \pm 1.8$ & $25.7 \pm 1.9$ & $22.5 \pm 2.1$ \\
\hline Mannose & $5.0 \pm 2.6$ & $4.7 \pm 0.6$ & $4.7 \pm 0.9$ & $5.0 \pm 1.5$ & $4.1 \pm 0.7$ & $5.4 \pm 1.8$ & $3.8 \pm 1.1$ & $4.9 \pm 1.6$ \\
\hline Galactose & $1.1 \pm 0.3$ & $1.0 \pm 0.2$ & $1.1 \pm 0.3$ & $1.1 \pm 0.2$ & $0.9 \pm 0.5$ & $0.8 \pm 0.1$ & $1.1 \pm 0.3$ & $1.2 \pm 0.3$ \\
\hline Glucose & $67.9 \pm 3.2$ & $67.5 \pm 2.0$ & $67.2 \pm 2.9$ & $68.8 \pm 2.1$ & $67.8 \pm 1.2$ & $66.9 \pm 2.4$ & $68.2 \pm 2.7$ & $69.5 \pm 2.6$ \\
\hline
\end{tabular}

Data given as mean \pm standard deviation $(n=5)$ as percentage of total sugars 
Pulp characterization

Table 3 summarizes the extractives content of the sapwood and heartwood fractions used for the pulping experiments and the resulting pulp yield, kappa number, and viscosity.

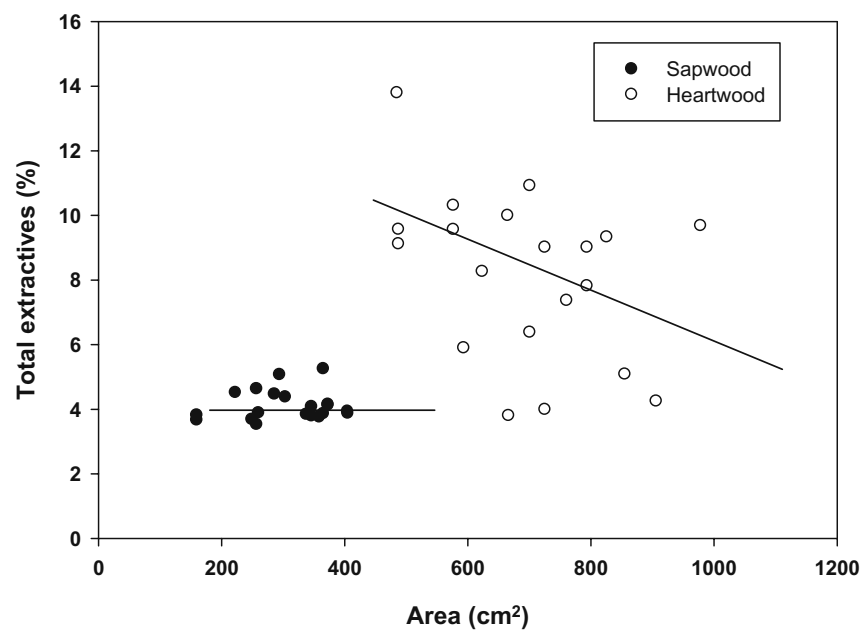

Fig. 1. Variation of total extractive content in heartwood and sapwood of Acacia melanoxylon trees grown in four sites with their respective cross-sectional area at $5 \%$ of stem height
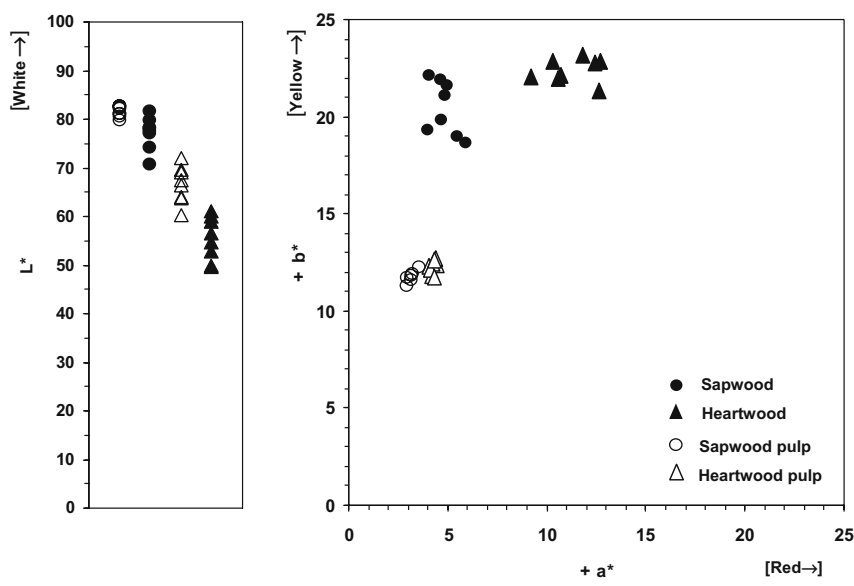

Fig. 2. Color values (CIE parameters $L^{*} a^{*} b^{*}$ ) of A. melanoxylon sapwood and heartwood (measured in 20-40 mesh samples) and of their unbleached pulps
The results of the kraft pulping showed an overall yield of $54.5 \%$ and low residual lignin (mean kappa number of 9). Similar pulp yield values of $55.7 \%$ and $53.2 \%$ with a kappa number of 11 were found by Gil et al. ${ }^{34}$ and Santos et al. ${ }^{28}$ using whole stems of $A$. melanoxylon as raw material.

Differences were found in the pulping of heartwood and sapwood (Table 3) with the pulp yield of heartwood $3.3 \%$ below that of sapwood. This is explained by the higher extractive content in the heartwood samples $(9.2 \%$ vs $3.8 \%$ in sapwood). This negative influence of extractives in pulping was also reported by Miranda et al. ${ }^{35,36}$ and Gominho and Pereira ${ }^{37}$ for E. globulus.

The effect of heartwood on the delignification degree was small under the pulping conditions used, although heartwood pulps had somewhat higher kappa numbers (11 vs 7). Consequently, the effect on cellulose was also small and similar values were obtained for pulp viscosities (Table $3)$. However, the mean pulp viscosity found here was less than the values reported by Gil et al. ${ }^{34}$ and Santos et al. ${ }^{28}$ for the same species $(1089 \mathrm{ml} / \mathrm{g}$ and $980 \mathrm{ml} / \mathrm{g}$, respectively), suggesting that under the pulping conditions used, the cooking time was excessive and may require optimization for this wood material.

The content of hexeneuronic acid groups $\left(C_{\mathrm{HexA}}\right)$ was higher in heartwood pulps than in sapwood pulps (27-45 $\mu \mathrm{mol} / \mathrm{g}$ and $11-29 \mu \mathrm{mol} / \mathrm{g}$, respectively) (Fig. 3), but overall was below the values reported by Chai et al. ${ }^{25}$ for hardwood pulps $(39.6-69.3 \mu \mathrm{mol} / \mathrm{g})$. Depending on the bleaching reagents and the sequence used, this fact can be an advantage for the bleachability of pulps obtained from A. melanoxylon wood because the presence of hexeneuronic acids in pulp generally has negative effects in bleaching and affects the kappa number determination. ${ }^{38}$

The brightness of heartwood pulps was on average $28 \%$, considerably below the $49 \%$ brightness of sapwood pulps and showed little variation between samples (Fig. 4). The color parameters of the unbleached pulps are presented in Fig. 2. In relation to the original wood, the pulps showed a more uniform color with a reduction in $a^{*}$ and $b^{*}$ parameters and an increase in $L^{*}$. There were differences between heartwood and sapwood pulps that could be visually ascertained and that were quantified mostly by a lower lightness of heartwood pulps (66.6 vs 81.6) and of brightness $(28 \%$ vs $49 \%$ ) (Fig. 4). This lower brightness of heartwood pulps

Table 3. Total extractives in wood samples of A. melanoxylon used for pulping, unbleached pulp yields, kappa number, and pulp viscosity

\begin{tabular}{|c|c|c|c|c|c|c|c|c|}
\hline \multirow[t]{2}{*}{ Sample } & \multicolumn{2}{|c|}{ Total extractives (\%) } & \multicolumn{2}{|c|}{ Total yield (\%) } & \multicolumn{2}{|c|}{ Kappa number } & \multicolumn{2}{|c|}{ Viscosity $(\mathrm{ml} / \mathrm{g})$} \\
\hline & Sapwood & Heartwood & Sapwood & Heartwood & Sapwood & Heartwood & Sapwood & Heartwood \\
\hline $1 \mathrm{H}^{\mathrm{a}}$ & 3.8 & 10.9 & 58.2 & 52.9 & 7 & 11 & 572 & 743 \\
\hline $1 \mathrm{M}^{\mathrm{a}}$ & 3.9 & 7.8 & 55.8 & 52.1 & 8 & 9 & 691 & 730 \\
\hline $2 \mathrm{H}$ & 3.7 & 9.7 & 55.6 & 53.1 & 7 & 10 & 729 & 757 \\
\hline $2 \mathrm{M}$ & 3.7 & 8.3 & 61.4 & 54.9 & 5 & 10 & 530 & 733 \\
\hline $3 \mathrm{H}$ & 3.9 & 13.8 & 53.6 & 49.6 & 9 & 14 & 729 & 870 \\
\hline $3 \mathrm{M}$ & 3.9 & 7.4 & 54.5 & 52.4 & 8 & 11 & 695 & 712 \\
\hline $4 \mathrm{H}$ & 3.5 & 9.6 & 56.6 & 55.2 & 6 & 10 & 651 & 708 \\
\hline $4 \mathrm{M}$ & 3.7 & 6.4 & 54.6 & 53.0 & 8 & 10 & 730 & 797 \\
\hline Mean & $3.8 \pm 0.1$ & $9.2 \pm 2.3$ & $56.2 \pm 2.5$ & $52.9 \pm 1.7$ & $7 \pm 1$ & $11 \pm 2$ & $666 \pm 77$ & $756 \pm 54$ \\
\hline
\end{tabular}

a Samples selected in sites 1 to 4 according to heartwood extractive content: H, highest; M, average 


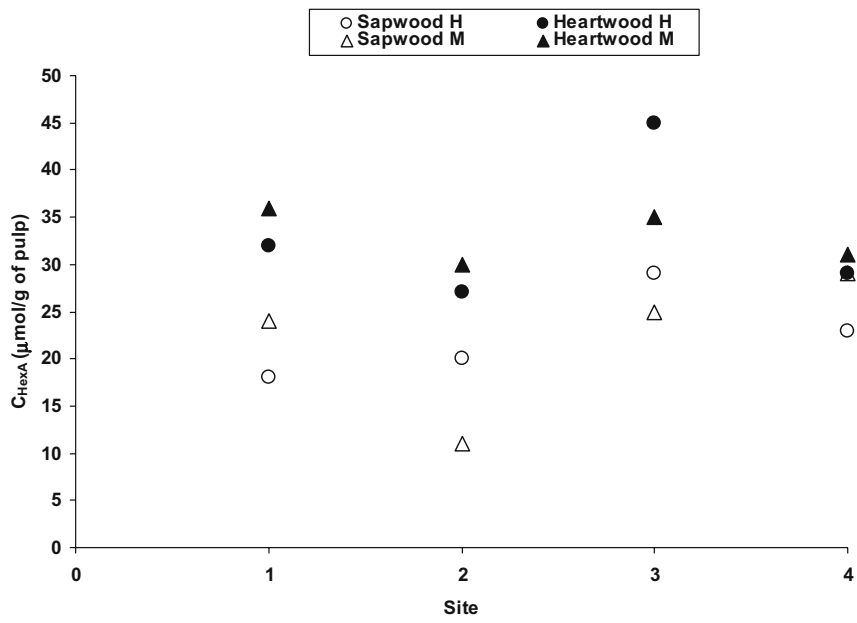

Fig. 3. Variation of hexeneuronic acid content in pulps obtained from sapwood and heartwood of $A$. melanoxylon trees grown in four sites. Samples selected in each site according to heartwood extractive content: $H$, highest; $M$, average

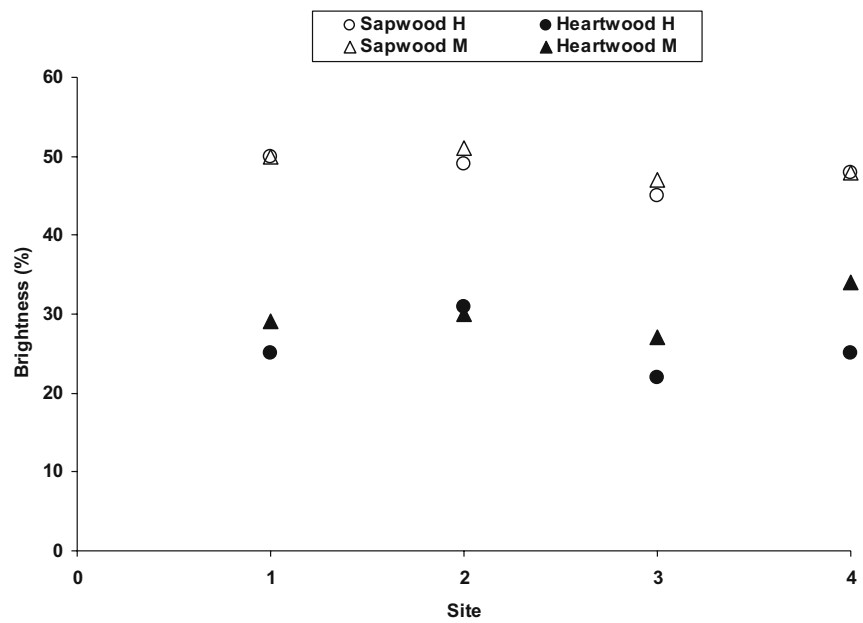

Fig. 4. Variation of brightness of pulps obtained from sapwood and heartwood of $A$. melanoxylon trees grown in four sites. Samples selected in each site according to heartwood extractive content: $H$, highest; $M$, average

has a negative impact because they result in higher consumption of bleaching chemicals. Gil et al. ${ }^{34}$ reported $45 \%$ brightness for the same species, 37\% for Acacia longifolia, and $41 \%$ for $A$. dealbata.

\section{Conclusions}

Acacia melanoxylon wood showed an overall good pulping aptitude in regard to chemical composition, with low lignin content leading to high kraft pulp yields and welldelignified pulps. There were chemical differences between heartwood and sapwood that influenced the pulping results. Heartwood contained on average twice the amount of extractives, while yield and brightness of heartwood pulps were lower than those of sapwood pulps. Considering that
A. melanoxylon stems may contain a large proportion of heartwood, its content should be considered as a quality variable when using A. melanoxylon wood because its presence decreases the raw-material quality for pulp industries.

Acknowledgments The authors thank Fatima Tavares and Sofia Knapic, who supplied the material; Mamadú Camará and Joaquina Silva, who helped with chemical analysis; and Anna-Stiina Jääskeläinen for providing pulp samples for $C_{\mathrm{HexA}}$ calibration. Financial support was given by Fundação para a Ciência e Tecnologia (Portugal) through the programme Fundo Europeu de Desenvolvimento Regional/Programa Operacional "Ciência, Tecnologia, Inovação" (FEDER/POCTI) to Centro de Estudos Florestais and the project AGR/42594/2001.

\section{References}

1. Miller J, Murphy D (2005) Many Acacia species, little genetic variation: DNA sequencing and the use of the microarray platform for inferring relationships among closely related species. In: XVII International Botanical Congress - Abstracts. Vienna, Austria, 17-23 July 2005, p 10. http://www.ibc2005.ac.at/program/abstracts/ IBC2005 Abstracts.pdf. Accessed January 2007

2. Seigler DS (2003) Phytochemistry of Acacia - sensu lato. Biochem Syst Ecol 31:845-873

3. Humphries CJ (1996) Guia Fapas. Árvores de Portugal e Europa. JR, Porto, pp 212-216

4. Leite A, Santos C, Saraiva I, Pinho JR (1999) O planeamento florestal e as espécies invasoras. $1^{\circ}$ Encontro Invasoras Lenhosas, Gerês, 16-18 November, Sociedade Portuguesa de Ciências Florestais, Lisbon, pp 49-55

5. Tavares M, Campos J, Saporiti J, Daniel C (1999) Formas de valorização do material lenhoso das Acacia dealbata, A. melanoxylon e A. longifolia. $1^{\circ}$ Encontro Invasoras Lenhosas, Gerês, 16-18 November, Sociedade Portuguesa de Ciências Florestais, Lisbon, pp 157-170

6. Pinkard EA (2003) Growth and physiological responses of blackwood (Acacia melanoxylon) growing with a Pinus radiata nurse crop following applications of nitrogen and phosphorus. Trees 17:325-335

7. Khristova P, Kordsachia O, Daffalla S (2004) Alkaline pulping of Acacia seyal. Trop Sci 44:207-215

8. Mbuna JJ, Mhinzi GS (2003) Evaluation of gum exudates from three selected plant species from Tanzania for food and pharmaceutical applications. J Sci Food Agric 83:142-146

9. Santos AJA, Anjos OMS, Simões RMS (2006) Papermaking potencial of Acacia dealbata and Acacia melanoxylon. Appita J 59:58-64

10. Pinto PC, Evtuguin DV, Neto CP (2005) Effect of structural features of wood biopolymers on hardwood pulping and bleaching performance. Ind Eng Chem Res 44:9777-9784

11. Neto CP, Silvestre AJD, Evtuguin DV, Freire CSR, Pinto PCR, Santiago AS, Fardim P, Holmbom B (2004) Bulk and surface composition of ECF bleached hardwood kraft pulp fibres. Nord Pulp Pap Res J 19:513-520

12. Phillips FH, Logan AF, Balodis V, Ward JV (1991) Studies on pulpwood resources in southern Tasmania. Part 1 kraft pulps. Appita J 44:85-90

13. Collins DJ, Pilotti CA, Wallis AFA (1990) Correlation of chemical composition and kraft pulping properties of some Papua New Guinea reforestation woods. Appita J 43:193-198

14. Xu EC (1999) Properties and papermaking potential of alkaline peroxide mechanical pulp from Acacia mangium. Appita J 52: $121-125$

15. Paavilainen L (1998) Quality-competitiveness of Asian short-fibre raw materials in different paper grades. Jaakko Pöyry Magazine $1: 4-8$

16. Wallis AFA, Wearne RH, Wright PJ (1996) Analytical characteristics of plantation eucalypt woods relating to kraft pulp yields. Appita J 49:427-432 
17. Miranda I, Pereira H (2001) Provenance effect on wood chemical composition and pulp yield for Eucalyptus globulus Labill. Appita J 54:347-351

18. Lange W, Hashim R (2001) The composition of the extractives from unaffected and heart rot affected heartwood of Acacia mangium Willd. Holz Roh Werkst 59:61-66

19. Pietarinen SP, Willför SM, Sjöholm RE, Holmbom BR (2005) Bioactive phenolic substances in important tree species. Part 3: knots and stemwood of Acacia crassicarpa and A. mangium. Holzforschung 59:94-101

20. Gominho J, Rodrigues J, Pereira H (2005) Clonal variation and influence of extractives of in Eucalyptus globulus Labill. kraft pulping. In: ChemPor 2005, 9th International Chemical Engineering Conference, Universidade de Coimbra, 21-23 September, Coimbra

21. Gominho J, Pereira H (2000) Variability of heartwood content in plantation grown Eucalyptus globulus Labill. Wood Fiber Sci 32: 189-195

22. Miranda I, Gominho J, Lourenço A, Pereira H (2006) The influence of irrigation and fertilization on heartwood and sapwood contents in 18-years-old Eucalyptus globulus trees. Can J Forest Res 36:2675-2683

23. Knapic S, Tavares F, Pereira H (2006) Heartwood and sapwood variation in Acacia melanoxylon R. Br. trees in Portugal. Forestry 79:371-380

24. Harrison CM (1974) Heartwood content patterns in Acacia melanoxylon in the southern cape. Forest South Afr 15:31-34

25. Chai XS, Zhu JY, Li J (2001) A simple and rapid method to determine hexeneuronic acid groups in chemical pulps. J Pulp Pap Sci 27:165-170

26. Fengel D, Wegener G (1983) Wood: chemistry, ultrastructure, reactions. Walter De Gruyter, Berlin, pp 106-127

27. Pereira H, Graça J, Rodrigues JC (2003) Wood chemistry in relation to quality. In: Barnett JR, Jeronimidis G (eds) Wood quality and its biological basis. CRC, Oxford, UK, pp 53-83

28. Santos A, Simões R, Pereira H, Anjos O (2004) Alternative species for the forest industry as forms of diversify the landscape. I Ibero-
American Symposium on Forest Management and Economics, 19-20 September, Barcelona, Spain

29. Pereira H (1988) Variability in the chemical composition of plantation eucalypts (Eucalyptus globulus Labill.). Wood Fiber Sci 20: $82-90$

30. Miranda I, Pereira H (2002) The variation of chemical composition and pulping yield with age and growth factors in young Eucalyptus globulus. Wood Fiber Sci 34:140-145

31. Hillis WE (1962) Wood extractives and their significance to the pulp and paper industries. Academic, New York, p 513

32. Morais CM, Pereira H (2004) Variability of sapwood, heartwood and extractives in Eucalyptus globulus Labill. Proceedings of IUFRO Conference on Eucalyptus in a Changing World. Aveiro, Portugal, p 697

33. Gominho J, Figueira J, Rodrigues JC, Pereira H (2001) Within-tree variation of heartwood, extractives and wood density in eucalypt urograndis (Eucalyptus grandis $\times$ E. urophylla). Wood Fiber Sci 33:3-8

34. Gil C, Amaral ME, Tavares M, Simões R (1999) Estudo do potencial papeleiro da Acácia spp. $1^{\circ}$ Encontro Invasoras Lenhosas, Gerês, 16-18 November, Sociedade Portuguesa de Ciências Florestais, Lisbon, pp 171-178

35. Miranda I, Tomé M, Pereira H (2003) The influence of spacing on wood properties for pulping in Eucalyptus globulus Labill. pulpwood. Appita J 56:140-144

36. Miranda I, Gominho J, Lourenço A, Pereira H (2007) Heartwood, extractives and pulp yield of three Eucalyptus globulus clones grown in two sites. Appita J 60:485-488

37. Gominho J, Pereira H (2005) The influence of tree spacing in heartwood content in Eucalyptus globulus Labill. Wood Fiber Sci 37:582-590

38. Sjöström E (2006) Do hexeneuronic acid groups represent the majority of the carboxyl groups in kraft pulps? J Wood Chem Technol 26:283-288 